\title{
Convergence of Non-financial Companies' Capital Structure in Central and Eastern Europe ${ }^{1}$
}

\author{
Peter KRIŠTOFÍK - Lea ŠLAMPIAKOVÁ - Jana FENDEKOVÁ*
}

\begin{abstract}
This paper explores the convergence of financial systems in selected CEE countries, by examining the typical capital structure, and its convergence, of their non-financial companies. It examines the sigma convergence of ratios of the most important financial liabilities to total financial liabilities. It focusses on those liabilities that constitute a significant part of total liabilities. These are equity and investment fund shares, bank loans, debt securities and trade credit. Using the Eurostat database, there is strong evidence for sigma convergence of equity and bank loans. This confirms the banking sector's key role in continental Europe. In contrast, debt securities and trade credit show only moderate convergence. The 2008 crisis led to increased variance for debt securities and trade credit.
\end{abstract}

Keywords: sigma convergence, companies' capital structure, equity, bank loans, trade credit, debt securities

JEL Classification: G01, G03

DOI: https://doi.org/10.31577/ekoncas.2021.03.02

\section{Introduction}

The last three decades have seen important changes in the financial structure of institutions because of liberalization, innovation and globalization. These phenomena have raised the importance of looking at differences and similarities between national financial systems. Financial convergence has come to be considered a significant aspect of integration. Hence a growing number of studies

* Peter KRIŠTOFÍK - Lea ŠLAMPIAKOVÁ - Jana FENDEKOVÁ, Matej Bel University in Banská Bystrica, Faculty of Economics, Department of Finance and Accounting, Tajovského 10, 97590 Banská Bystrica, Slovakia; e-mail: peter.kristofik@umb.sk; lea.slampiakova@umb.sk; jana.oncakova@gmail.com

${ }^{1}$ This work has been supported by the Scientific Grant Agency of Slovak Republic under project VEGA No. VEGA 1/0579/21 Research on Determinants and Paradigms of Financial Management in the Context of the COVID-19 Pandemic. 
focus on the links between and the convergence of financial systems and economic growth. This paper focuses on the convergence of the financial liabilities of non-financial corporations in CEE countries.

Despite extensive research, Myers (1984) well-known question "How do companies choose their capital structure?" remains unanswered. The trade-off theory assumes that in order to achieve optimal capital structure, firms balance their tax shield benefits against the growing costs of financial discomfort. Taxpaying companies aim to increase their levels of debt until bankruptcy beckons (Kraus and Litzenberger, 1973). Myers and Majluf (1984) proposed the pecking order theory. Based on the idea of asymmetric information, it assumes that companies do not have a target debt level. They prefer internal financing, because it is cheaper. But if they must use outside capital, they prefer debt to equity. Though this theory is the most popular explanation of company capital structure choices, Corbett and Jenkinson (1996) note that no theory explains all cross-country variations in firms' capital structures.

While the theories focus on deriving optimal solutions that would apply to all company managements, empirical studies examine why managers solve given issues differently. For instance, La Porta et al. (1997) studied differences in the legal environment companies face. They showed that different legal environments significantly impact the nature of corporate financing. Berglof and Claessens (2004) claim that "Enforcement more than regulations, laws-on-the-books, or voluntary codes is a key to effective corporate governance, at least in transition and developing countries. Corporate governance and enforcement mechanisms are intimately linked as they affect firms' ability to commit to their stakeholders, in particular to external investors. The limited empirical evidence suggests that private tools are more effective than public forms of enforcement in the typical environment of most developing and transition countries." In other words, using the principles of corporate governance should help firms access external financing.

Baele et al. (2004) show that EU countries have made considerable progress in developing common rules in financial markets, as well as providing equal access to financial instruments or services in those markets. Some theorists argue that globalization, deregulation, economic integration, regulatory harmonization and rules, as well as corporate governance, lead to convergence in the main characteristics of financial systems.

Several studies confirm that the original European continental system is starting to resemble the Anglo-Saxon system, and that the classic distinction between market-based and bank-based systems is no longer as relevant as it was in the past (Allen and Gale, 2000; Holzl, 2006). 
Based on this perspective, companies' financial structures have converged on a model that combines elements of the Anglo-Saxon model, where market-based loans predominate over bank loans, with the characteristics of a continental European system, where bank services are dominant. Moreover, during $1980-2005$ most countries worldwide adopted at least some of the free market policy that has proved to be an important element in ensuring economic growth and real convergence (Balcerowicz and Fischer, 2006, p. 1).

However, the question is whether financial convergence will occur alongside the real one. Briefly said, the aim of this paper is to examine the convergence of financial systems by investigating the capital structure of their non-financial companies. The reason for analyzing companies' debt ratios, is that their choice of corporate debt instruments provides information about the general characteristics of financial systems. The analysis uses two overlapping data sets. First it concentrates on CEE countries, and then on those CEE countries that use the euro. The remainder of the paper is structured as follows. Section 1 reviews the literature on the convergence of financial systems. Section 2 describes methods and data. Section 3 summarizes the empirical results using the Gini index of convergence, and section 4 provides the empirical results of a cluster analysis of convergence. Subsequently, authors draw some conclusions.

\section{Review of the Literature}

Schmidt, Hackethal and Tyrell (2002) examined the development of the financial systems of Germany, France and Great Britain for the period 1980 - 1988. Their hypothesis of convergence of financial systems was unconfirmed. The German financial system remained bank oriented, while the British continued to be market oriented. The French system was more difficult to classify, as it underwent substantial changes in market organization.

Hartman, Maddaloni and Manganelli (2003) compared the structure of the financial system of the euro area, the United States and Japan for the period 1995 - 2001. The Eurozone was bank-oriented, even if considerably less so than in the past. For institutional investors, the traditional role of banks in providing financial services had decreased. Hackethal and Schmidt (2004) studied firms' financing patterns in Germany, Japan and the US. They used data based on the gross flow of companies' financial sources. The results of their empirical research confirmed their initial assumption that the financial systems of the countries varied considerably, and that this had a significant influence on companies' capital structures.

Mylonidis and Kollias (2010) examined the dynamic process of convergence in the securities markets of four of the most advanced European countries. They 
found slight convergence had occurred, in an ongoing process. Antzoulatos, Panopoulou and Tsoumas (2011) tested for financial systems' convergence during $1990-2005$, for a global sample of 38 countries. Not only did they fail to find convergence, but they claimed to have found deepening divergence in some countries.

Bruno, De Bonis and Silvestrini (2012) explored sigma and beta convergence of financial asset structures in OECD countries. They found strong evidence for convergence in shares and insurance. But for securities and deposits the evidence was mixed. The latter result they attributed to variations in the structure of different financial systems, and in the roles of banks across systems. The research of Kılınç, Seven and Yetkiner (2017) focused on convergence in EU financial development, from a wider perspective. Their aim was to verify whether the transition from the European Monetary System to the single currency led to the integration of financial markets. They found that both banking and securities markets had tended to converge across the EU.

In a very extensive study, Leon (2017) reported on convergence tests on the credit structures of 143 countries for $1995-2014$. He found that convergence of the household credit structure was faster than convergence of the corporate credit structure. He also found that the convergence process was faster in low-income countries, and in countries where original indebtedness was low. However, this process slowed down after the 2008 crisis.

Barucci and Colozza (2018) recognized that there had been a significant change in non-financial corporate financing during the crisis. In the pre-crisis period (1997 - 2007) corporations had relied heavily on bank loans. But after 2008 there was a rise in securities issuances, and a moderate decline in bank loans. In other words, the crisis led to a shift away from bank loans towards securities as a way of financing activities.

This literature search leads us to expect that we will find a convergence of companies' capital structures in CEE countries, especially in the pre-crisis period. As the 2008 crisis affected CEE economies in differing degrees, we would expect a wider divergence in the spread of companies' financial liabilities after that date. But by now the convergence process should have reappeared.

\section{Measurement and Data}

When measuring the convergence rate, we used the Gini coefficient, which is a characteristic indicator of sigma convergence. The Gini coefficient is calculated from the Lorenz curve and is calculated using the formula:

$$
G=\frac{A}{A+B}
$$


The Gini coefficient is defined as a ratio of the areas on the Lorenz curve diagram. The area between the line of perfect equality and the Lorenz curve is A, and the area under the Lorenz curve is B.

Fig u re 1

\section{Gini Coefficient Expressed by the Lorenz Curve}

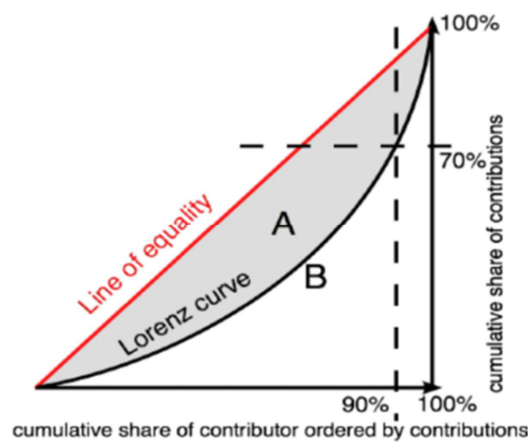

Source: Own processing; from Bellú, Liberati (2006).

The Gini index quantifies the difference between the empirical cumulative data distribution, and an ideal even distribution. The index is an analytical measure of concentration, and can takes values from zero to one. Its minimum value of zero expresses perfect equality, and its maximum value of one reflects total inequality in the cumulative frequency distribution. If the index takes a value near the upper limit of its interval, it means that there is significant inequality, and large disparities in the surveyed data.

The sigma convergence analysis was chosen instead of the beta one for several reasons. First, we were interested in convergence development across the whole of the examined period, and especially during the run up to and aftermath of the 2008 crisis. Sigma convergence, unlike beta convergence, can show if there is a monotonic process of development during a given period, or if there are subperiods of both convergence and divergence. Secondly, Quah (1993) and Friedman (1992) both suggest that sigma convergence is of greater interest because it speaks directly as to whether the examined distribution is becoming more equitable. Moreover, Young, Higgins and Levy (2008) showed that beta convergence is a necessary but not a sufficient condition for sigma convergence.

We also use cluster analysis to examine the companies' capital structure. Data clustering is a technique used in many areas including data mining and pattern recognition. It involves the division of the original data set into multiple subsets (clusters) in such a way that the data in each subset has several common characteristics (Abonyi and Fell, 2007). Specifically, based on the number of our analyzed 
objects (11 countries), we used agglomerative hierarchical clustering, which can be described as a "bottom-up" algorithm. This type of clustering technique is appropriate for identifying small clusters. This is in contrast to divisive clustering, which works in "top-down" manner, and is good at identifying large clusters.

To perform the cluster analysis, we standardized the variables in the data sets to make them comparable. Among many cluster agglomeration methods, we chose Ward's minimum variance one. This minimizes the total within-cluster variance. At each step the pair of clusters that have minimum between-cluster distance are merged. The graphical representation of this process is a dendrogram. In the dendrogram, each object is first displayed separately. As we move to the left, objects that are similar to each other are combined into branches, which are themselves fused at a higher height. The height of the fusion, noted on the horizontal axis, indicates the (dis)similarity/distance between the two objects/ clusters (Kassambara, 2017).

We performed this analysis for three years: at the beginning of the examined period in 2001; in 2008, since we were interested in the impact of the crisis on companies' financial choices; and then in 2017, at the end of the examined period. We carried out cluster analyses by using Ward linkage: a method used to evaluate the distance between clusters. Cluster membership is estimated by calculating the total sum of squared deviations from the mean of a cluster.

There are several general conceptual ways to analyze financing structures and financing patterns. We can either examine data on gross flows for particular financial instruments, or data on net flows. That is, gross inflows minus gross outflows for the same type of instrument. Moreover, for both options we can either examine individual company accounts, or the sector aggregates that are reported by national statistics authorities. Most databases contain data on net flows.

Data from individual company accounts is much more detailed than aggregate sectoral data. Therefore, panel analysis is possible. However, company level data is usually only available for large companies and, therefore, is not necessarily representative of all companies' capital structure. Providers of national accounts have standardized reporting of net flows, as well as sector definitions and classifications of financial instruments. This has led to improvements in international data comparability and historical availability. But the high level of aggregation makes regression analysis difficult.

Our general approach to measuring companies' financial choices is based on data from the Eurostat database. Data on national accounts in that database are governed by the regulation: The European System of National and Regional Accounts (ESA, 2018). Non-financial corporations are defined as those whose main activity is the production of goods, or the provision of non-financial services. 
That includes legally established companies, branches of non-resident companies, landowners, and residential non-profit institutions that are producers of goods or providers of non-financial services.

In the Eurostat database, financial liabilities appear in several accounts. For our analysis we focused on those liabilities that constitute a significant part of total liabilities: namely, equity and investment funds, debt securities, bank loans and trade credit. We tested for the convergence of companies' capital structure, by examining the ratio of individual financial accounts to total financial liabilities. It is important to note that the total value of liabilities in our analysis is slightly lower than $100 \%$, because we have omitted accounts of insignificant value. We used the stated values of financial liabilities, usually given for the beginning or end of the accounting period. The states between two such periods will vary, depending on transactions and other flows.

The equity and investment fund accounts for an important part of the companies' capital structure in all the examined countries, although the spread in its values is relatively high. It should also be clear that financing through shares issue is limited to listed companies - mostly large corporations, which represents only a fraction of the total corporate sector. Bank loans are also a significantly important component of corporate liabilities. Debt securities are, on the other hand, a debt instrument that is less widely used by firms.

Trade credit is a source of external financing that is important for an enterprise, but does not reach significant values for the aggregate sector. While other accounts payable represents an important part of companies' liabilities, especially in certain countries, the other accounts receivable is also a significant part of total assets. In other words, what is a payable for one company is a receivable for another. This means that after aggregation across the whole corporate sector, trade credit is of diminished importance. In our paper we calculate trade credit as the difference between payables and receivables in relation to total liabilities. This figure could be negative. Our data set covers the CEE countries, Croatia, The Czech Republic, Estonia, Hungary, Latvia, Lithuania, Poland, Romania, Slovakia and Slovenia, for the period 2001 - 2017. We focused on CEE countries that are members of the EU. For some countries, data series go back to the second half of the 1990s. Only from 2001 is it available for all these countries.

\section{Empirical Results: Convergence}

In this paper we analyze the convergence of companies' capital structure; focusing on the more significant financial instruments of equity and investment funds, debt securities, bank loans and trade credit. Convergence is measured by 
the Gini index, representing sigma convergence. If its value are within the interval $\langle 0 ; 0.3)$ there is a strong convergence. If the values are from the interval $<0.3 ; 0.7)$, the convergence is moderate. Values above 0.7 indicate very slight to no convergence. Our results are shown in Graph 1.

Graph 1

Development of the Gini Coefficient in the CEE Companies' Capital Structure $2001-2017$

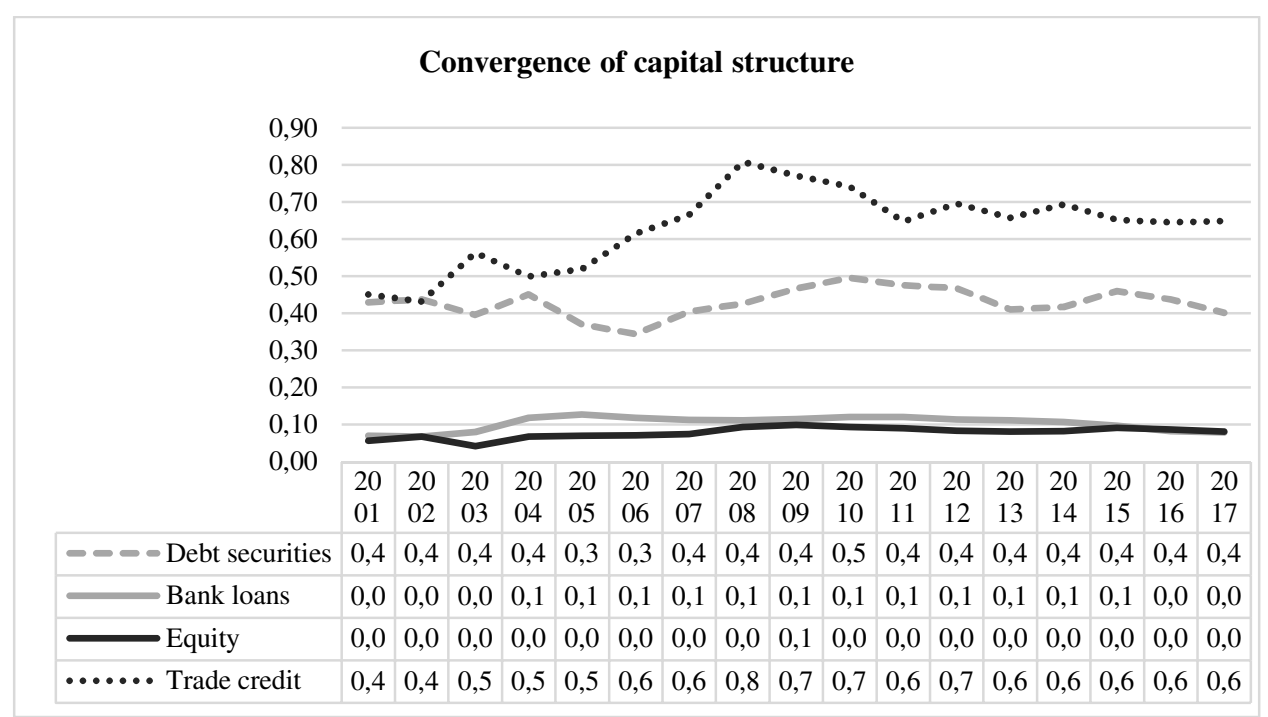

Source: Own processing; data from Eurostat.

The results of convergence in equity are shown by the Lorenz curve. The solid black line in Graph 1 shows the development of convergence of the ratio of equity and investments funds to total liabilities. The Gini index achieves the lowest values for this component of companies' capital structure, so convergence is the strongest. Over the entire examined period the convergence is within the interval $\langle 0.04 ; 0.10\rangle$ therefore we can describe it as exhibiting extremely strong convergence. During the crisis there was a slight divergence, since the highest value of Gini index was in 2009, but after then the convergence process again intensified. Graph 2 includes a line of equality as well as Lorenz curves of equity for 2001, 2008 and 2017. All the distributions are very close to the line of equality, but convergence was strongest in 2001.

The Eurostat data shows that bank loans and equity form the largest parts of the companies' capital structure. As in the case of equity, we can see strong convergence (solid black line in Graph 1), since the Gini coefficient is lower than 0.3 for all the examined period. However, the convergence of bank loans is slightly weaker than the convergence of equity. The interesting fact is that the 
convergence was strongest during 2001 and 2002. But by 2005 the value of the Gini index had increased by 0.06 . However, it then began a long, slow decline to 2017. It seems that the crisis did not have direct impact on the level of bank loans. These results also feature in Graph 3, where the Lorenz curves for 2001 and 2017 are almost identical, while in 2008 there was moderate divergence.

Graph 2

Lorenz Curve; Convergence of Equity in 2001, 2008 and 2017

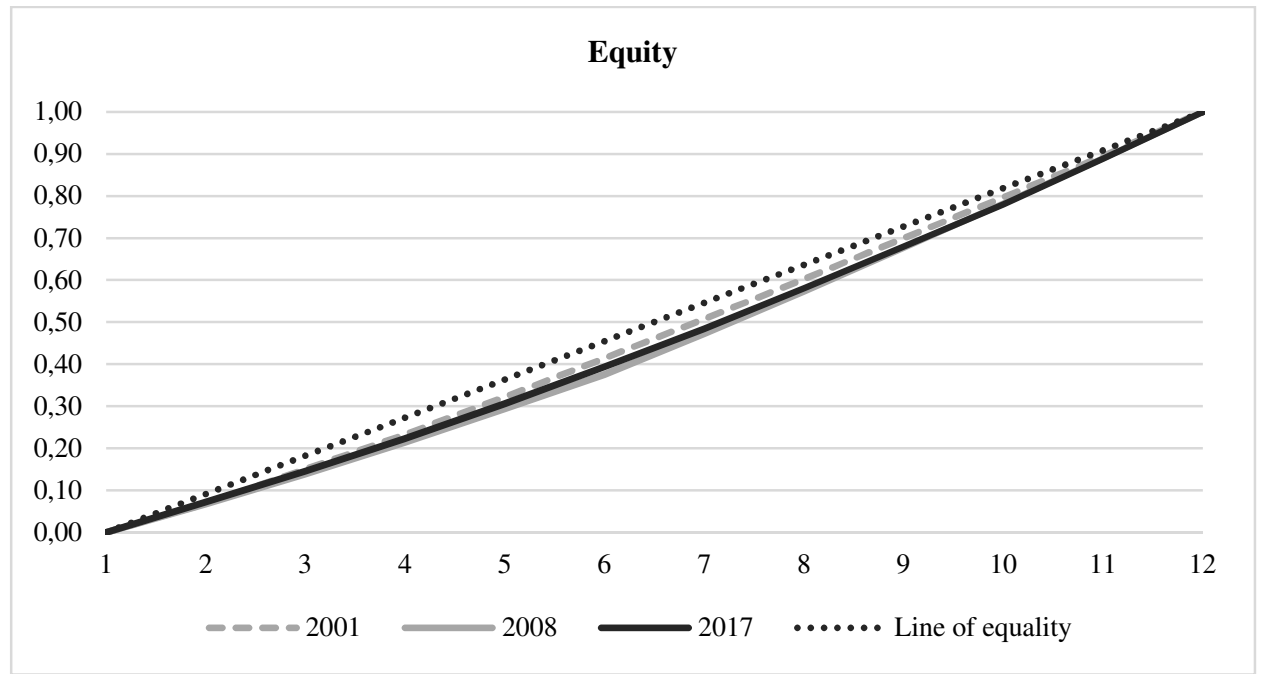

Source: Own processing. Data from Eurostat.

Graph 3

Lorenz Curve; Convergence of Bank Loans in 2001, 2008 and 2017

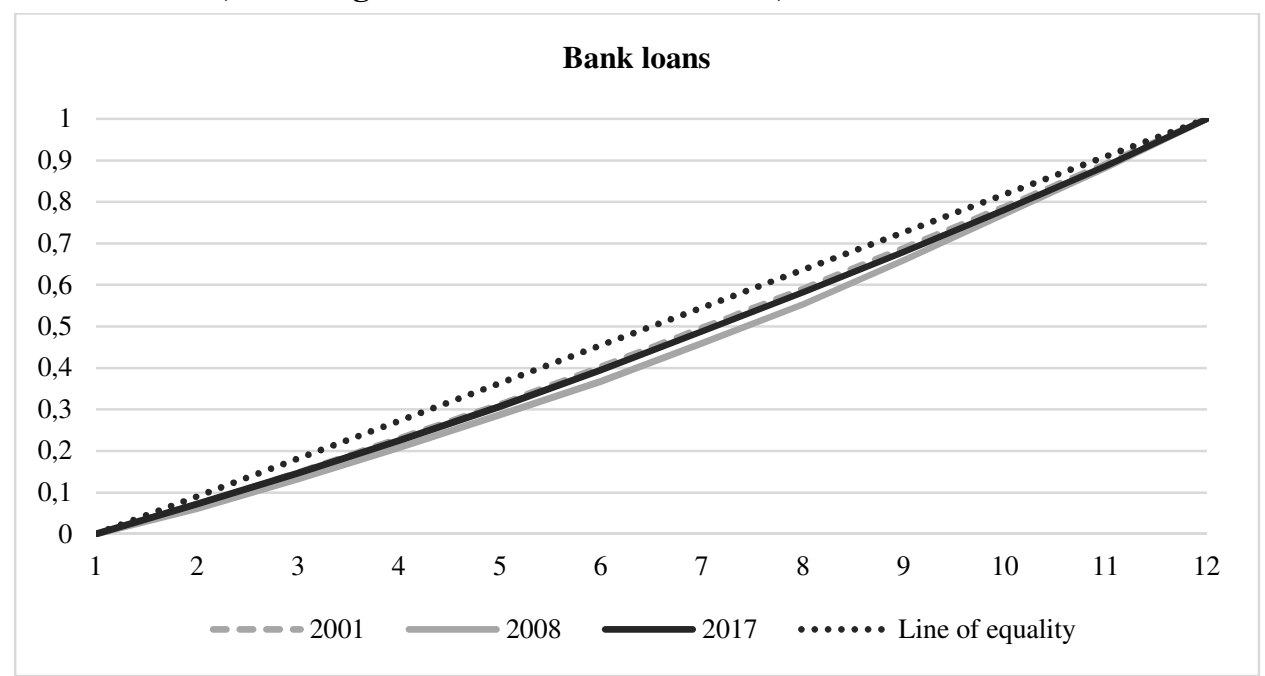

Source: Own processing. Data from Eurostat. 
The dashed line in Graph 1 shows that the Gini index values for the debt securities account of non-financial corporations, fall in the interval $\langle 0.34 ; 0.50\rangle$. Overall, this means moderate convergence. However, the strongest convergence was in the pre-crisis year of 2006. On the other hand, the highest value of the Gini index was in 2010, but the intensity of convergence started to decrease in 2008. The crisis had a slightly different impact on the convergence of debt securities, compared to that on the convergence of other financial liabilities. But the differences, shown in Graph 4, are so slight as perhaps to be insignificant.

Graph 4

Lorenz Curve; Convergence of Debt Securities in 2001, 2008 and 2017

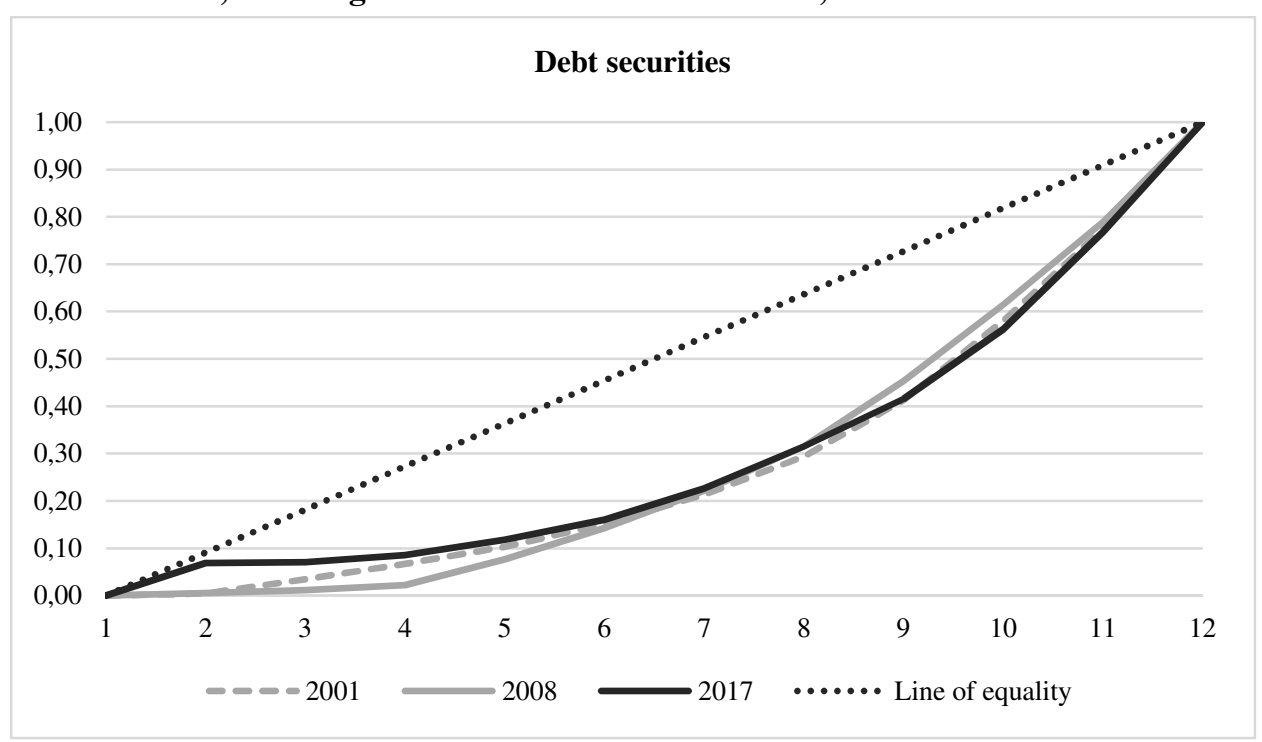

Source: Own processing. Data from Eurostat.

Trade credit is a source of companies' funding that is particularly important for countries with Anglo-Saxon financial systems. In continental Europe, and especially in the past, bank loans were used a great deal. But as we noted in section 3, as we use aggregate, net corporate sector data, trade credit does not seem to be a significant component of the capital structure of most countries. We calculated the values of trade credit as the difference between liabilities and receivables, as a ratio to total liabilities. Therefore, the values are rather low or even negative in some countries during some periods. On the other hand, there are other countries, such as Romania or Latvia, where trade credit amounts to more than $10 \%$ of total capital structure.

In Graph 1, the dotted line, represents the Gini coefficient for non-financial companies' trade credit. It is clear that trade credit is the most volatile component 
of the capital structure for CEE companies. The index values lie in the interval $<0.43 ; 0.81>$. So, there is moderate to weak convergence. During the crisis, there is strong evidence of a divergence process. Later, convergence started to quicken, but it is still the weakest amongst all of the financial instruments.

Graph 5 shows Lorenz curves for trade credit in 2001, 2008 and 2017. The divergence is clearly the greatest amongst all of the examined liabilities, during the whole period.

Graph 5

Lorenz Curve; Convergence of Trade Credit in 2001, 2008 and 2017

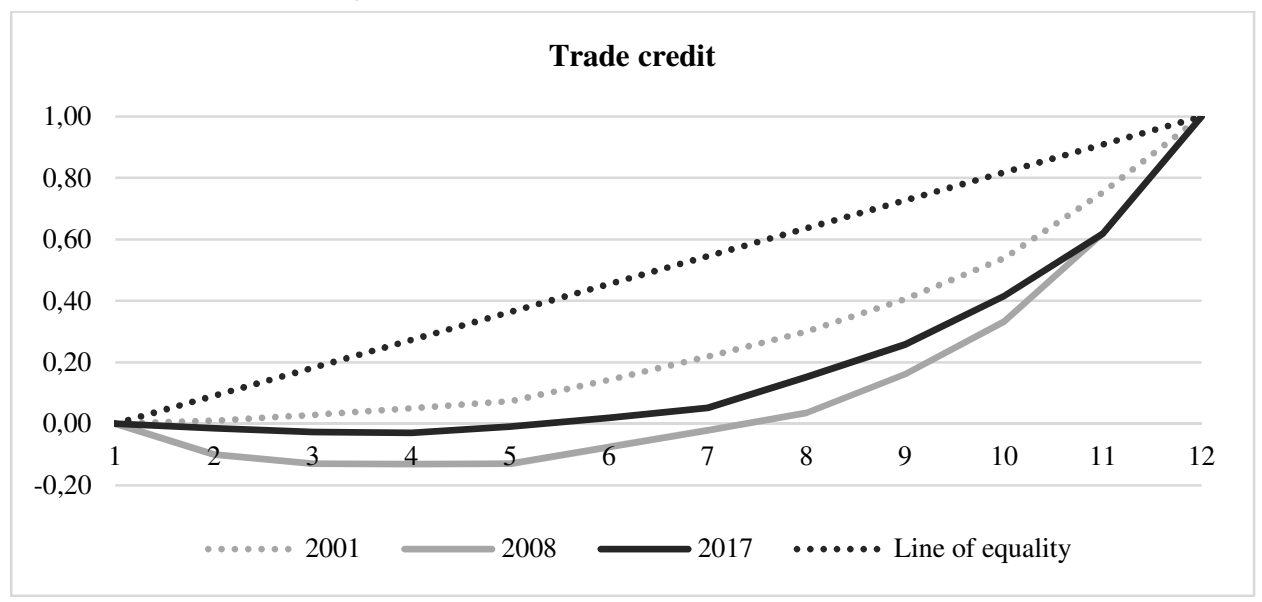

Source: Own processing according to Eurostat database.

\section{Empirical Results: Cluster Analysis}

We also examine the items using cluster analysis. A dendrogram reveals the clusters. The further to the left the clusters lie, the more similar are the sample countries' capital structures.

\subsection{Cluster Analysis for 2001}

The dendrogram is based on the relative shares of individual financial liabilities to total company liabilities. The ratios for 2001 are shown in Table 1 . The data source is Eurostat. Equity and investment funding accounted for around $50 \%$ of companies' capital structure, but debt securities were no more than $3 \%$. As noted above, the total value of the financial liabilities is less than $100 \%$, because we only included those liabilities that were significant for all countries in the sample. For example, we excluded both insurance and financial derivatives. 
T a ble 1

Ratios of Financial Liabilities to Total Liabilities in 2001 (in \%)

\begin{tabular}{|l|c|c|c|c|}
\hline $\begin{array}{l}\text { Country } \\
\text { 2001 }\end{array}$ & Debt securit. & Bank loans & Equity & Trade credit \\
\hline Bulgaria & 1 & 29 & 56 & 7 \\
Czech Republic & 3 & 27 & 55 & 5 \\
Estonia & 2 & 33 & 53 & 5 \\
Croatia & 1 & 31 & 56 & 1 \\
Latvia & 0 & 36 & 47 & 9 \\
Lithuania & 1 & 27 & 50 & 6 \\
Hungary & 0 & 33 & 36 & 2 \\
Poland & 3 & 30 & 53 & 15 \\
Romania & 1 & 25 & 52 & 1 \\
Slovenia & 0 & 32 & 47 & 2 \\
Slovakia & 3 & 23 & & \\
\hline
\end{tabular}

Source: Own processing. Data from Eurostat.

Graph 6

Capital Structure of CEE Companies in 2001

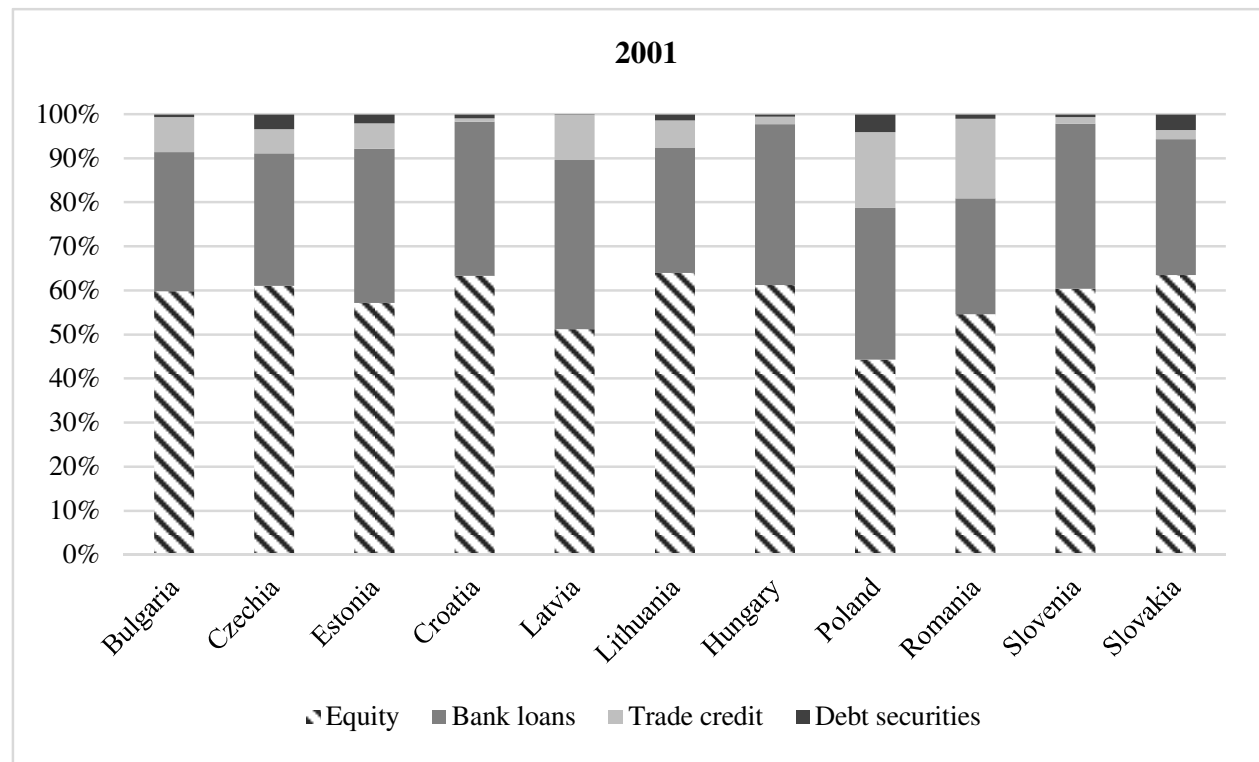

Source: Own processing. Data from Eurostat.

Two clusters of countries were created at distance 8 . The first cluster is much the larger, comprising Croatia, Hungary, Estonia, Slovenia, Bulgaria, the Czech Republic, Lithuania and Slovakia. For this group, equity accounts for 54\% of companies' capital structure. Bank loans, at 19\%, form the second most important component of companies' financing. The other debt instruments used by companies are trade credit (4\%), and debt securities (1\%). On average, $28 \%$ of their financial structure comprises liabilities that we have not examined in our study. These could include insurance, pension funds and financial derivatives. 
The second cluster of countries consists of Latvia, Poland and Romania. Equity and investment funds still account for the greatest proportion of funding, but at $46 \%$ are much lower than for the first cluster. On this basis we can assume that the leverage is higher in these countries. Bank loans are the most important debt instrument as they form $30 \%$ of companies' capital structure. Also noteworthy is the much greater importance of trade credit, at $14 \%$. At $1 \%$ the ratio of debt securities is the same as it was for the first cluster.

De ndrogram 1

\section{Capital Structure of Non-financial Companies in 2001}

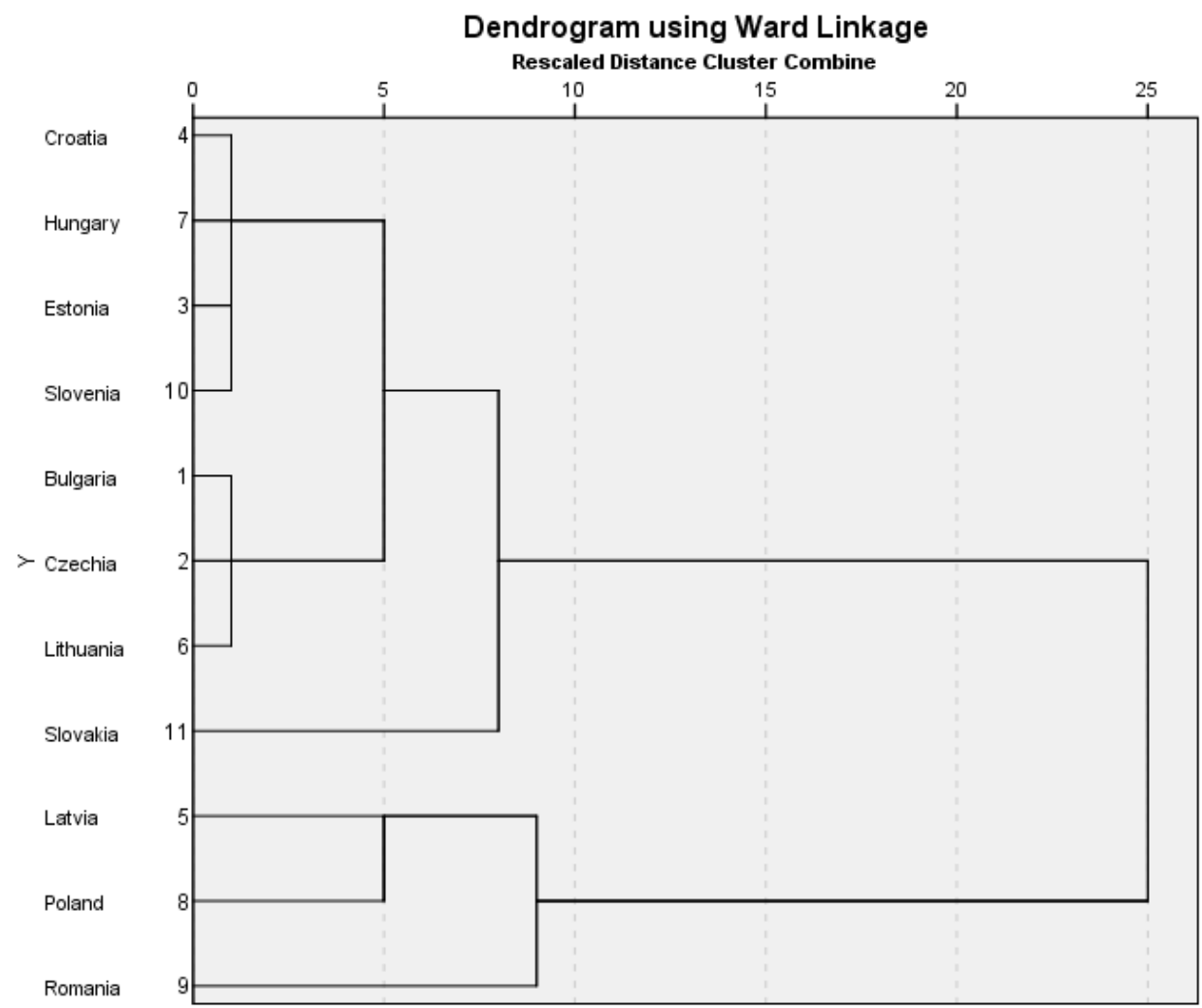

Source: Own processing. Data from Eurostat.

\subsection{Cluster Analysis in 2008}

Dendrogram 2 is based on the data presented in Table 2. Equity and investment shares were still a very important part of companies' capital structure, but it is important to note that in some countries bank loans increased so significantly that their share was even higher than equity. Such a situation occurred in no CEE countries, in either 2001 or in 2017. 
Table 2

Ratios of Financial Liabilities to Total Liabilities in 2008 (in \%)

\begin{tabular}{|l|c|c|c|c|}
\hline Country & Debt securit. & Bank loans & Equity & Trade credit \\
\hline Bulgaria & 1 & 47 & 38 & 8 \\
Czech Republic & 2 & 26 & 56 & 6 \\
Estonia & 2 & 38 & 53 & 0 \\
Croatia & 2 & 47 & 41 & 3 \\
Latvia & 0 & 45 & 34 & 14 \\
Lithuania & 0 & 33 & 55 & 3 \\
Hungary & 1 & 40 & 51 & 3 \\
Poland & 2 & 30 & 53 & 19 \\
Romania & 0 & 34 & 41 & 0 \\
Slovenia & 1 & 49 & 37 & -5 \\
Slovakia & 1 & 31 & 49 & \\
\hline
\end{tabular}

Source: Own processing. Data from Eurostat.

Graph 7

Capital Structure of CEE Companies in 2008

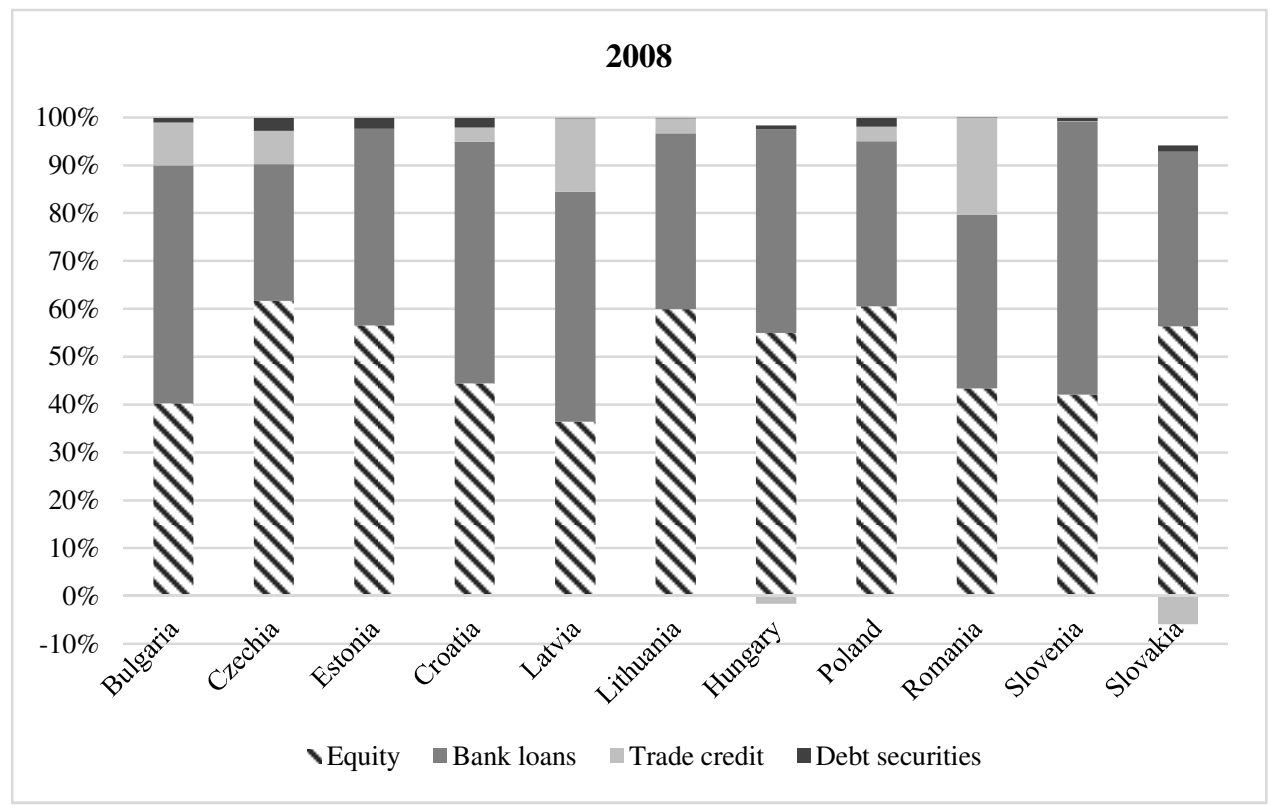

Source: Own processing. Data from Eurostat.

We performed a cluster analysis for 2008, because we wanted to investigate the impact of the crisis on CEE counties' financial systems. The crisis had a significant impact on companies' behavior. 3 clusters of countries were identified at distance 7, while in the last cluster there is only Romania, which has a unique capital structure. The first cluster comprises the 6 original countries: Hungary, Estonia, Bulgaria, The Czech Republic, Lithuania and Slovakia. Their 
corporate behavior related to funding their investments had changed little. Equity was still the most important element, forming $53 \%$ of total liabilities - down from $54 \%$ in 2001 . Their debt structure had changed more: bank loans were up from $19 \%$ to $33 \%$. On the other hand, trade credit had decreased from $3 \%$ to $1 \%$; while debt securities remained at $1 \%$.

Of the original second cluster for 2001, only Romanian companies' behavior had changed significantly by 2008 . In particular bank loans had risen from $25 \%$ to $34 \%$ of funding, while equity had fallen from $53 \%$ to $41 \%$. A third cluster comprised the remaining countries: Croatia, Slovenia, and Bulgaria from the original first cluster, and Latvia from the original second cluster. The relevant finding is that leverage is highest here, as equity forms only $37 \%$ of companies' capital structure. The most important financial liability in these countries is bank loans, at $47 \%$. Trade credit is at $6 \%$, and debt securities at $1 \%$.

D e n d rog ram 2

Capital Structure of Non-financial Companies in 2008

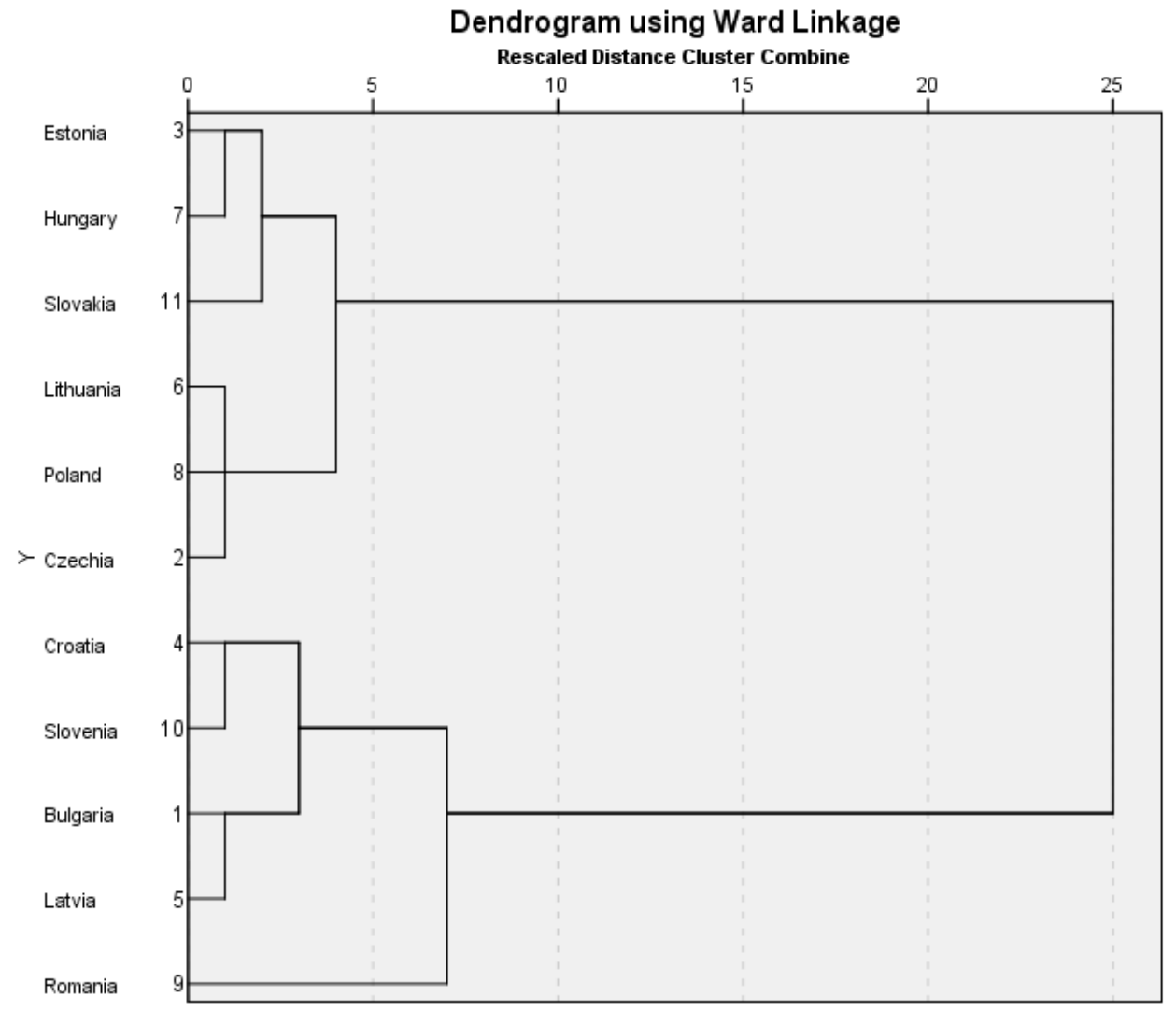

Source: Own processing. Data from Eurostat. 


\subsection{Cluster Analysis in 2017}

Table 3 shows the 2017 ratios of financial liabilities to total liabilities. The most important parts of companies' capital structures comprise equity and investment shares. In all countries the ratio of bank loans decreased, compared to 2008. The ratio of debt securities also increased; mainly in the Czech Republic and Slovakia.

T a b le 3

Ratios of Financial Liabilities to Total Liabilities in 2017 (in \%)

\begin{tabular}{|l|c|c|c|c|}
\hline Country & Debt securit. & Bank loans & Equity & Trade credit \\
\hline Bulgaria & 2 & 32 & 57 & 1 \\
Czech Republic & 5 & 24 & 55 & 5 \\
Estonia & 2 & 26 & 63 & 1 \\
Croatia & 2 & 38 & 48 & 5 \\
Latvia & 0 & 35 & 44 & 9 \\
Lithuania & 1 & 25 & 57 & 7 \\
Hungary & 1 & 28 & 62 & -1 \\
Poland & 4 & 29 & 52 & 1 \\
Romania & 0 & 33 & 42 & 0 \\
Slovenia & 2 & 34 & 50 & -1 \\
Slovakia & 6 & 31 & 41 & \\
\hline
\end{tabular}

Source: Own processing. Data from Eurostat.

Graph 8

\section{Capital Structure of CEE Companies in 2017}

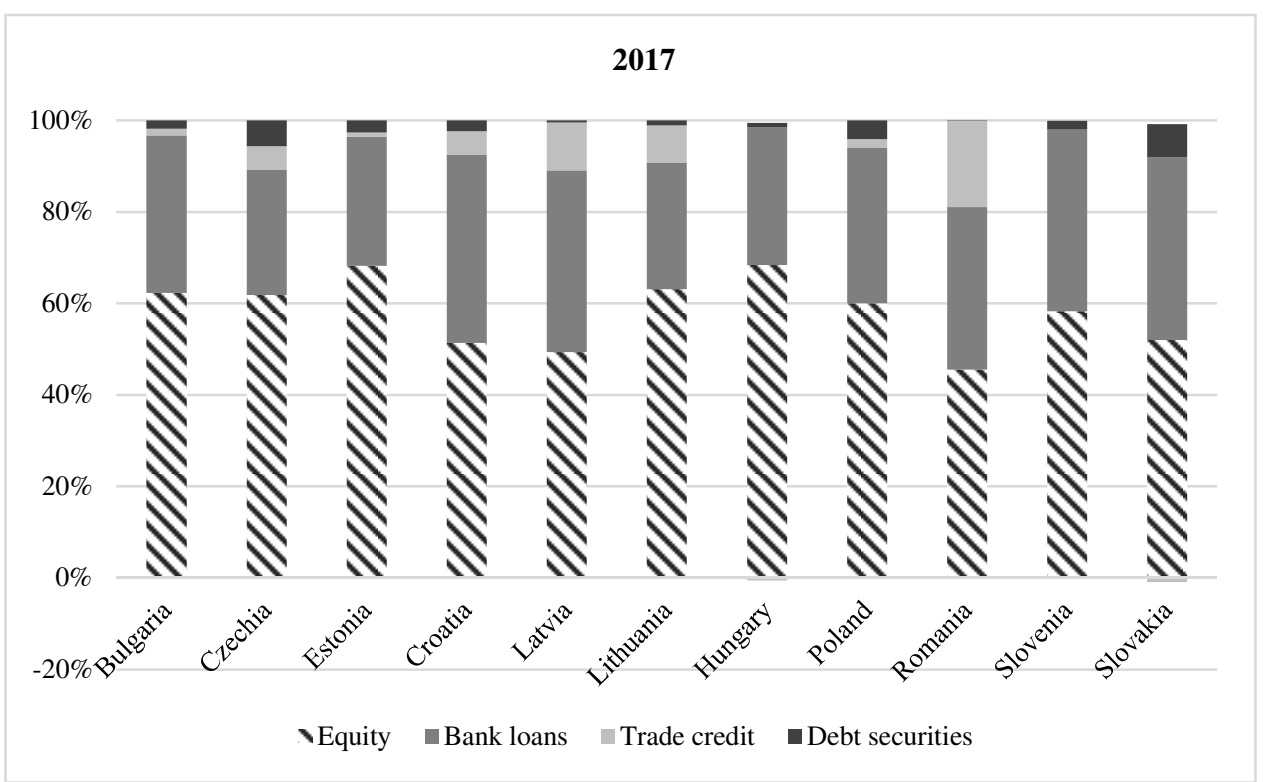

Source: Own processing. Data from Eurostat. 
The cluster analysis shows that the convergence of countries had increased by 2017 , since the clusters were created at distance 6 . The first cluster consists of countries whose equity and investment shares account for the largest part (59\%) of companies' capital structures. These countries include Estonia, Hungary, the Czech Republic and Lithuania. Compared to 2008, Slovakia and Bulgaria have left this cluster. On average bank loans account for $25 \%$ of the present members' capital structure, trade credit $3 \%$, and debt securities $2 \%$.

By 2017, Latvia and Croatia had joined the 2008 single member cluster of Romania. The own resources of companies in those countries accounted for $44 \%$ of their companies' capital structures. Trade credit was still significantly important, at $19 \%$ of total liabilities. Bank loans were at $35 \%$, and debt securities at $1 \%$. The final cluster contains Poland, Bulgaria, Slovenia, and Slovakia, where equity and investment shares are at or over $50 \%$ for the first three, and $40 \%$ for Slovakia. Bank loans represent $32 \%$ of total liabilities, and debt securities $3 \%$. Trade credit is, on average, $0 \%$.

De ndrogram 3

Capital Structure of Non-financial Companies in 2017

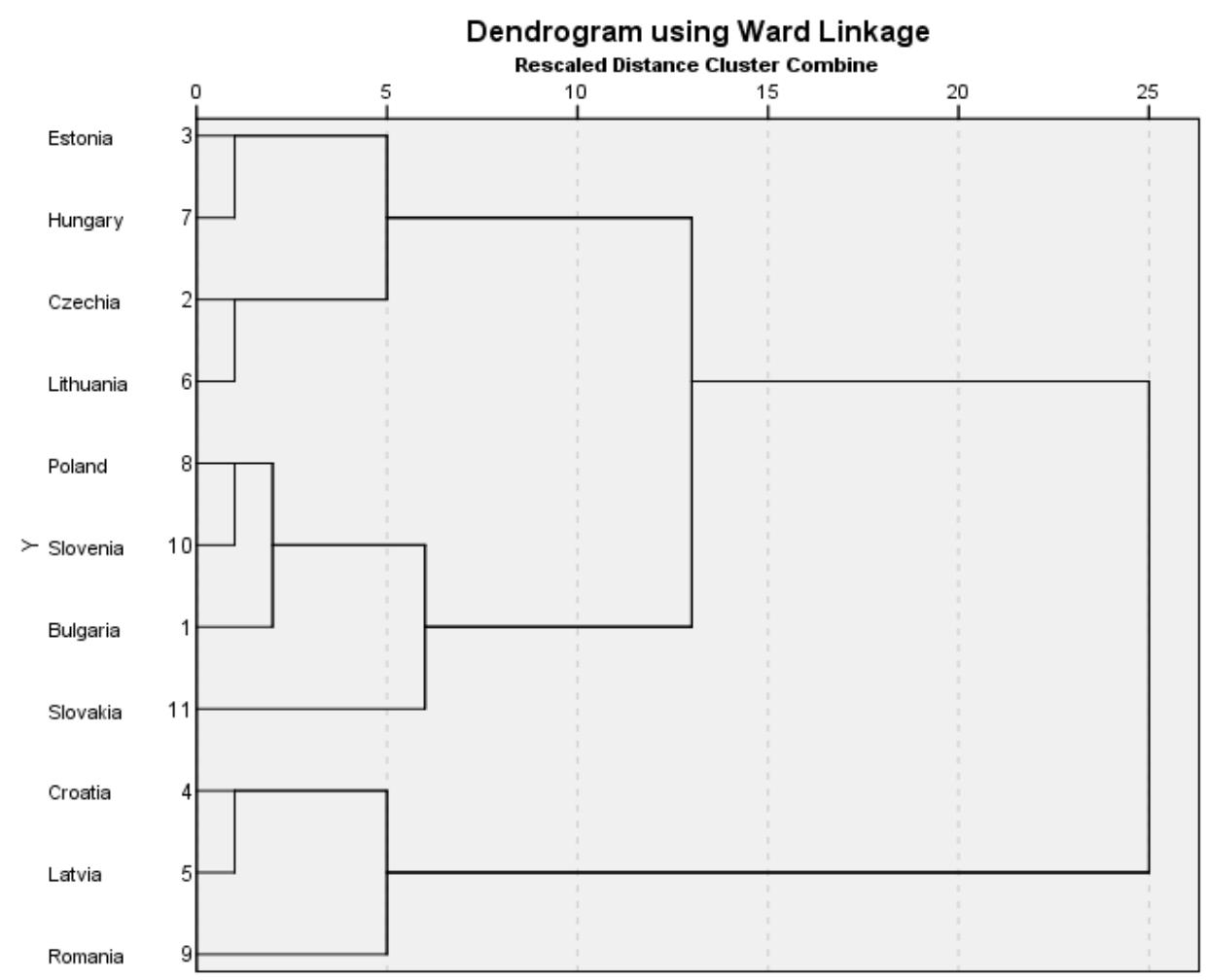

Source: Own processing. Data from Eurostat. 


\section{Concluding Remarks}

This study examined the convergence of companies' financial liabilities equity and investment funds, bank loans, debt securities and trade credit - in the countries of Central and Eastern Europe, between 2001 and 2017. The analysis's working assumption was that firms' capital structures, and changes in them, can provide important clues to explain the development of countries' financial systems.

We used sigma convergence, as we were interested in convergence development across the whole of the examined period, and especially during the run up to and aftermath of the 2008 crisis. Sigma convergence, unlike Beta convergence, can show if there is a monotonic process of development during a given period, or if there are both convergent and divergent sub-periods.

The results provide strong evidence for convergence of equity and investment shares, as well as for bank loans. These findings support the presumption of the importance of banking systems in continental European countries. There have been research claims that continental Europe is moving towards Anglo-Saxon style financial systems (Léon, 2017). But those studies show much greater shifts in household credit than in companies' credit structures. It seems that the traditional features of an Anglo-Saxon financial system - such as the key roles of stock exchanges, trade credit and private pension funds - spread faster through countries' household sectors than through their company sectors.

Secondly, empirical evidence suggests a weaker convergence for debt securities and trade credit. These results may reflect economic, or non-economic factors, such as the culture, traditions or habits of the given countries. Thirdly, during the crisis there is evidence of divergence in all the examined financial liabilities, except for bank loans. The characteristics of exhibiting both volatility during the examined period, and divergence during the crisis, is strongest for trade credit. After 2011, the convergence of all financial instruments started to increase, but it was not as strong as it had been in 2001 .

Future research might follow several different directions. First, it would be interesting to see if extending the time series back into the past, supports this paper's findings. Second, in the future we might predict stronger and faster convergence in the structure of household credit, specifically an increase in investment in pension funds and insurance products, alongside a decrease in the importance of bank loans. Third, it would be worthwhile to extend the convergence analysis to other European countries. For example, the impact of the single currency on the convergence of a country's financial system could also be tested at the EU level. Fourth, it could be beneficial to compare the convergence process in these countries using the data from set of individual companies. Finally, there is also an ongoing process of international rule-making, specifically in the banking sector 
and the derivatives market. The new standards will increase the similarities in the rules governing different national financial systems, and so it will be interesting to see if these changes lead to the convergence of their financial structures.

\section{References}

ABONYI, J. - FELL, B. (2007): Cluster Analysis for Data Mining and System Identification. New York City: Springer Science \& Business Media, pp. 47 - 80. ISBN 978-3-7643-7988-9.

ALLEN, F. - GALE, D. (2000): Comparing Financial Systems. Cambridge, MA: The MIT Press. ISBN 978-0-2625-1125-4.

ANTZOUlATOS, A. A. - PANOPOUlOU, E. - TSOUMAS, C. (2011): Do Financial Systems Converge? Review of International Economics, 19, No. 1, pp. $122-136$.

BAELE, L. - FERRANDO, A. - HORDAHL, P. - KRYLOVA, E. - MONNET, C. (2004): Measuring Financial Integration in the Euro Area. [ECB Occasional Paper Series 14.] Frankfurt am Main: ECB.

BALCEROWICZ, L. - FISCHER, S. (2006): Living Standards and Wealth of Nations. Successes and Failures in Real Convergence. Cambridge, MA: The MIT Press. ISBN 978-0-2620-2595-9.

BARUCCI, E. - COLOZZA, T. (2018): European Financial Systems in the New Millennium: Convergence or Bubble? Available at: <https://ssrn.com/abstract=3212861> or <http://dx.doi.org/10.2139/ssrn.3212861>.

BERGLOF, E. - CLAESSENS, S. (2004): Enforcement and Corporate Governance. [World Bank Policy Research Working Paper Series 3409.] Washington, DC: The World Bank. Available at: <http://documents.worldbank.org/curated/en/516141468765315959/Enforcement-andCorporate-Governance>.

BRUNO, G. - De BONIS, R. - SILVESTRINI, A. (2012): Do Financial Systems Converge? New Evidence from Financial Assets in OECD Countries. Journal of Comparative Economics, 40, No. 1 , pp. $141-155$.

CORBETT, J. - JENKINSON, T. (1996): The Financing of Industry, 1970 - 1989: An International Comparison. Journal of the Japanese and International Economies, 10, No. 1, pp. $71-96$.

FRIEDMAN, M. (1992): Do Old Fallacies Ever Die? Journal of Economic Literature, 30, No. 4, pp. $2129-2132$.

HACKETHAL, A. - SCHMIDT, R. H. (2004): Financing Patterns: Measurement Concepts and Empirical Results. [Working Paper Series: Finance \& Accounting, No. 125.] Frankfurt am Main: Johann Wolfgang Goethe-Universität Frankfurt am Main.

HARTMAN, P. - MADDALONI, A. - MANGANELLI, S. (2003): The Euro-Area Financial System: Structure, Integration, and Policy Initiatives. Oxford Review of Economic Policy, 19, No. 1 , pp. $180-213$.

HOLZL, W. (2006): Convergence of Financial Systems: Towards an Evolutionary Perspective. Journal of Institutional Economics, 2, No. 1, pp. 67 - 90.

KASSAMBARA, A. (2017): Practical Guide to Cluster Analysis in R. Unsupervised Machine Learning. 1st Edition. CreateSpace Independent Publishing Platform. ISBN 98-154242709.

KILINÇ, D. - SEVEN, Ü. - YETKINER, H. (2017): Financial Development Convergence: New Evidence for the EU. Central Bank Review, 17, No. 2, pp. 47 - 54.

KRAUS, A. - LITZENBERGER, R. H. (1973): A State-preference Model of Optimal Financial Leverage. Journal of Finance, 28, No. 4, pp. 911 - 922.

LA PORTA, R. - LAKONISHOK, J. - SHLIEFER, A. - VISHNY, R. (1997): Good News for Value Stocks. Journal of Finance, 47, No. 1, pp. 75 - 109.

LÉON, F. (2017): Convergence of Credit Structure around the World. Economic Modeling, 68, No. 1 , pp. $306-317$. 
MYERS, S. - MAJLUF, N. (1984): Corporate Financing and Investment Decisions When Firms Have Information Investors Do Not Have. Journal of Financial Economics, 13, No. 2, pp. 187 - 221.

MYERS, S. C. (1984): The Capital Structure Puzzle. Journal of Finance, 39, No. 3, pp. 575 - 592.

MYLONIDIS, N. - KOLLIAS, C. (2010): Dynamic European Stock Market Convergence: Evidence from Rolling Cointegration Analysis in the First Euro - Decade. Journal of Banking and Finance, 34, No. 9, pp. 2056 - 2064.

QUAH, D. T. (1993): Galton's Fallacy and the Convergence Hypothesis. Scandinavian Journal of Economics, 95, No. 4, pp. $427-443$.

SCHMIDT, R. H. - HACKETHAL, A. - TYRELL, M. (2002): The Convergence of Financial Systems in Europe. Schmalenbach Business Review, Special Issue 1, No. 2, pp. 7 - 53.

YOUNG, A. T. - HIGGINS, M. J. - LEVY, D. (2008): Sigma Convergence versus Beta Convergence: Evidence from U.S. County-Level Data. Journal of Money, Credit and Banking, 40, No. 5, pp. $1083-1093$. 